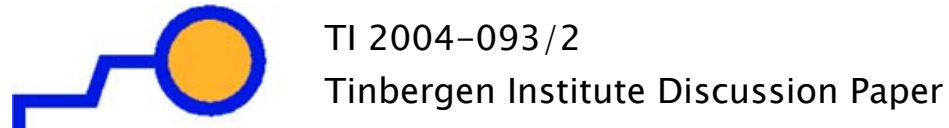 \\ National and International Income Dispersion and Aggregate Expenditures
}

Carmen Fillat ${ }^{1}$

Joseph Francois ${ }^{2}$

' universidad de Zaragoza, and Tinbergen Institute,

2 Faculty of Economics, Erasmus Universiteit Rotterdam, Tinbergen Institute, and CEPR.. 


\section{Tinbergen Institute}

The Tinbergen Institute is the institute for economic research of the Erasmus Universiteit Rotterdam, Universiteit van Amsterdam, and Vrije Universiteit Amsterdam.

Tinbergen Institute Amsterdam

Roetersstraat 31

1018 WB Amsterdam

The Netherlands

Tel.: $\quad+31(0) 205513500$

Fax: $\quad+31(0) 205513555$

Tinbergen Institute Rotterdam

Burg. Oudlaan 50

3062 PA Rotterdam

The Netherlands

Tel.: $\quad+31(0) 104088900$

Fax: $\quad+31(0) 104089031$

Please send questions and/or remarks of nonscientific nature to driessen@tinbergen.nl.

Most TI discussion papers can be downloaded at http://www.tinbergen.nl. 


\title{
National and International Income Dispersion and Aggregate Expenditures
}

\author{
Carmen Fillat \\ Universidad de Zaragoza
}

\author{
Joseph Francois \\ Tinbergen Institute (Erasmus \\ University) and CEPR
}

This version: August 2004

\begin{abstract}
We examine linkages between aggregate household income, distribution of that income, and aggregate cross-country expenditure patterns. We are able to decompose income effects into international income dispersion effects (from variations in average income) and national income dispersion (income distribution) effects. This yields insights for relevant aggregate household specifications in computational policy models emphasizing household distribution of income. This also yields a consumption-pattern based inequality index that summarizes the projection of inequality through expenditure patterns. Estimation of flexible demand systems with representative expenditures (which reflects income distribution within countries) yields a significant relationship between representative consumption and cross-country demand patterns.
\end{abstract}

Keywords: income distribution, aggregate demand, demand system estimation, Engel curves

JEL codes: $\quad$ D31, D12, D63, C68 


\section{Introduction}

There has been an increased interest in the linkages between national economic structures, changes in these structures vis-à-vis the global economy, and income distribution. This includes the general empirical evidence on the impact of international trade on income distribution and poverty in developing countries (Winters 2001, Winters et al 2003). It also includes the growing computational literature on the household impact of policy reform. Along these lines, Devarajan and van der Mennsbrugghe (2000) examine the household impact of trade policy reform in South Africa, Hertel et al (2004) explore the impact of multilateral trade liberalization on poverty reduction, Ianchovina et al (2000) examine reform and distribution in Mexico, Robillard et al (2001) focus attention on the recent crisis in Indonesia, and Khan focuses on tax reform in Bangladesh (1997).

The innovation in the recent computational literature is the integration of household survey data within empirically-based general equilibrium structures. This approach facilitates the explicit tracing of linkages between household incomes and economywide factor income and goods price effects to provide a more complete picture of the poverty and distributional impact of proposed policy reforms. A critical element of these models is the micro-demand system, which ultimately links household incomes, through prices, to demand for final goods. The underlying demand system obviously matters in this context. (Reimer and Hertel 2003.) At one extreme, assumptions about identical homothetic preferences can mean that there are no real linkages between aggregate demand and income distribution. We can then separate the problem of aggregate demand for goods (and the demand side closure of the aggregate economy) from household distribution. At the other extreme, highly non-homothetic properties may mean that redistribution of income, even holding initial total income fixed, may have profound effects on aggregate demand, and hence on the structure of production and trade. In addition, the interpretation of aggregate effects hinges on this point.

In this paper we examine apparent linkages between aggregate household income, distribution of that income, and aggregate expenditure patterns. We work with cross-country data from the International Comparison Project (ICP) on aggregate expenditures and prices, combined with cross-country data on household income/expenditure and its distribution. A basic question we address is whether aggregate demand patterns vary systematically across countries as a function of income distribution. There is evidence of this effect (for example Francois and Kaplan 1996) based on the pattern of trade. We estimate a flexible demand system. In contrast to the recent ICP-based literature, we take into account both the within and cross-country pattern of income distribution. (See for example Reimer and Hertel 2003). 
This involves the incorporation of in-country data on the household distribution of income. We find that while statistically significant, systematic nonlinear income or Engel curve effects related to income distribution are not the major driver of variations in expenditure patterns. The one exception is the distinction between expenditures on food and non-food items. This in turn means that for many modeling purposes, an appropriately specified single representative household may remain a reasonable approximation at the macroeconomic level, even in applications than involve computational modeling focused on the household distribution of income. The results suggest that the more ambitious approach in the recent computational literature, where non-homothetic demand systems are incorporated that allow for two-way linkages between the aggregate economy and household income distribution, and also between household income distribution and the aggregate economy, may yield similar information to that from applications where aggregate households are assumed. We also explore the use of expenditure patterns to measure income distribution. The most common income distribution indexes, such as the Gini coefficient and Atkinson index, are based on one-dimensional monetary measures of the distribution of income or of expenditure on consumption. In linking income expansion path (Engel-curve) estimates with household distribution data, we obtain an index of the dispersion of income, as it manifests itself in variations in aggregate expenditure patterns. We compare this index with Gini and Atkinson indexes summarizing income distribution patterns.

\section{Income expansion paths and inequality}

In this section, we examine the impact of income levels and income dispersion (inequality) on aggregate expenditure patterns across broad expenditure categories. Our interest is twofold. First, we are interested in comparing the relative contribution of actual variations in observed income levels, and variations in inequality, to variations in observed aggregate expenditure patterns. As discussed in the introduction, this is important given the current direction in the CGE literature on inequality. As a second point, we are also interested in using consumption data to index cross-country inequality patterns. To this end, we compare our consumption based income dispersion indexes with Gini coefficients and Atkinson index estimates, two commonly used income inequality indexes. The subsection deals with Engel curve estimation. This is followed by examination of sample variations in expenditure patterns, and comparisons of resulting income dispersion (inequality) measures. 


\section{$2.1 \quad$ Engel curves}

We work with data on expenditures, national incomes, and household expenditure/income shares. Expenditure data are from the Penn Word Tables (PWT) benchmark studies. Data on GDP are also taken from the PWT dataset, measured in thousands of dollars. Household income distribution data are from quintile data reported in the World Bank's World Development Indicators (WDI) data base. Once we match different data sources, we are left with 168 country-periods (observations) for 8 final demand categories. The countries and years are listed in Annex Table 1. Final demand categories are listed in Table 1.

When Engel curves are estimated from cross-country data, a standard implicit assumption is that consumers within each country have the same income. However, as the starting point for Engel curve analytics is that preferences are non-linear in income, aggregation of within-country demands implies that, when income is not equally distributed among the consumers within a single country, the country as a whole then does not act as if it is spending the average per capita income. To handle this, we estimate representative demand, which can serve analytically as the basis for aggregate cross-country expenditure patterns. With representative demand, we capture the interaction of income distribution with expenditure patterns.

Formally, we specify income expansion paths for expenditure shares as reflecting the impact of income changes on the share of expenditure devoted to each consumption category $i$. Ignoring distributional issues, national Engel curves then take the general form:

$$
\begin{aligned}
& w_{i}=\lambda_{i}+\mu_{i}\left(\frac{x}{k}\right)^{-\delta} \\
& \Delta \ln w_{i}=-\delta \mu_{i}[\Delta \ln (x)-\Delta \ln (k)]
\end{aligned}
$$

where $w_{i}$ is the share of expenditure in good $i, x$ is the income of the consumer, a country in this case, $k$ is the size of this country, and the parameters $\lambda_{i}$ and $\mu_{i}$ are functions of prices only. The parameter $\delta$ indicates the degree of nonlinearity of Engel curves, and only when $\delta=1$ will the function be a straight line. We re-index the functional form in equation (1) across households within a country. Indexing these households by $h$, household Engel curves are given by the function: 


$$
w_{i}^{h}=\lambda_{i}+\mu_{i}\left(\frac{x^{h}}{k^{h}}\right)^{-\delta}
$$

where $x^{h}$ is expenditure and the parameters are identical for every household.

Aggregation now involves a weighted average, where the weight is the income share of every household (and by scaling $k^{h}=1$ ). The result is the national pattern of expenditure, as follows:

$$
w_{i} \quad=\sum_{h} \frac{x^{h}}{\sum_{j} x^{j}} w_{i}^{h}=\lambda_{i}+\mu_{i} \sum_{h} \frac{\left(x^{h}\right)^{1-\delta}}{\sum_{j} x^{j}}=\lambda_{i}+\mu_{i} x_{o}^{-\delta}
$$

In equation (3), $x_{o}$ means the representative expenditure within the country, which is different from the average expenditure or income when the income distribution is unequal. Hence, this representative expenditure can be computed as:

$$
x_{o}=\left[\sum_{h} \frac{\left(x^{h}\right)^{1-\delta}}{\sum_{j} x^{j}}\right]^{-1 / \delta}
$$

This expression is linearly homogeneous in the $x^{\prime} \mathrm{s}$. This means that it is possible to write $x_{0}=k_{0} \bar{x}$, where $k_{o}$ summarizes the combined effects of nonlinear Engel curves and unequal distribution of expenditures and works as a scaling factor against mean household income $\bar{x}$. Furthermore, for a given value of $\delta, k_{o}$ can be estimated and interpreted as an indicator of dispersion. In general $k_{o}$ is decreasing in $\delta$ so that representative expenditure is above average expenditure if and only if $\delta$ is less than unity. (Deaton and Muelbauer 1980a)

To estimate $\delta$, while taking into account income distribution, the whole expression in (3) has to be taken. The expression to be estimated is:

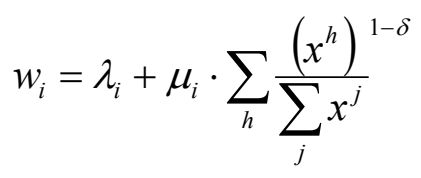


furthermore, $\Sigma \mathrm{x}^{\mathrm{h}}$ is the aggregate consumption expenditure in the country, $\mathrm{X}$.

$$
w_{i}=\lambda_{i}+\mu_{i} \sum_{h} \frac{\left(x^{h}\right)^{1-\delta}}{X}
$$

We have estimated equation (6) using non-linear full information maximum likelihood. The results are reported in Table 1. Turning first to the primary coefficient of interest, the estimated value for $\delta$ is highly significant. From the results for coefficients $\lambda$, four of eight final expenditure categories show a minimum expenditure share significantly different from zero. These are (1) Food, beverages and tobacco; (2) Clothing and footwear; (4) Furniture, household equipment and operation; and (7) Recreation, entertainment and education. Given the estimate for $\delta$, the implied income expansion paths (Engel curves) are clearly non-linear, implying a desirability to work with flexible demand systems for explicit demand system estimation (and possibly for computational modeling). We turn to this issue in Section 3, where we apply the Almost Ideal Demand (AID) System to our data.

[Table 1 about here]

\subsection{National vs. international dispersion}

The results in Table 1 suggest that, at least statistically, variations in both national income levels (international dispersion) and within-country income distribution (national dispersion) are important determinants of aggregate expenditure patterns. Yet, national dispersion is not necessarily as large as income dispersion at the international level. We turn now to decomposition of Engel effects into different mechanisms: the average income effect and the dispersion effect around this average. As an illustrative example, in Table 2 we compare the predictions from the estimated Engel curves for a country with sample average values. Such a country is one with average expenditure per quintile and average population. Income distribution data refer to distribution per quintile, so that the basic data are the average expenditures per quintile. We have scaled this information taking into account that every country has a different population per quintile in order to consider the equivalent per capita expenditure and quintile expenditure. The equivalent expenditure per quintile equals the per capita expenditure for each country multiplied by the scale factor of average population per 
quintile. This scale factor varies depending on the sub-sample of richer or poorer countries, as we also compare the predictions for the average higher income (rich) and lower-income (poor) countries in the sample in order to compare both effects for different levels of development.

\section{[Table 2, Figure 1 about here]}

In Table 2, the "income effect" rows compare the differences between predictions based on average incomes for high and low-income sub-samples, holding dispersion constant at the sample average. The "dispersion effect" columns compare differences in predicted values given maximum and minimum dispersion values in the sample, holding income constant at the average for each sub-sample. Turning first to income effects, the greatest resulting variations in expenditure shares are for the consumption of food. As a general rule, poor countries consume a larger share of necessities - mainly food and clothing - and a lower share of luxuries. To illustrate the relative magnitudes involved, Figure 1 presents the effects working from a country with full sample average values, as we alternatively vary dispersion while holding income at the average, and vary income while holding dispersion at the average. We have scaled the resulting predicted changes by the predicted income share in the case of average income and dispersion. The result in the figure gives a rough sense of relative changes in magnitude, in the sample, due to variations in the sample related to income levels and dispersion. For food, the income effect means a substantial difference amounting to roughly 11 percent of total expenditure and over 40 percent of the predicted food expenditure share around the average. Turning next to the dispersion effect, we see a similar pattern. The greatest effect is again for food consumption in absolute terms, though relative effects are comparably large for other final demand sectors as well, like housing, medical services, and other services. In relative terms, the income effect is roughly 3 times larger than the dispersion effect across the various demand categories. What does this tell us? Based on the variation in incomes and national dispersion in the sample, the range of international incomes implies a far greater variation in expenditure shares than does intracountry variations in income. Note also that implied interaction effects appear to be relatively small. For example, for food, the impact of variations in average national representative income on food demand in Table 2 is similar for the high and low sample values for intra-country dispersion in the sample. Similarly, the intra-country dispersion 
effect is roughly comparable for the high and low sample values for representative national income. Beyond food, these effects are virtually identical.

\subsection{Standard inequality indexes and the income dispersion index}

Starting with equation (4) and our estimate of $\delta$, we have also estimated the values of $k o$, hence combining the effects of income distribution and its impact on consumption. This index measures how the average income projects itself into representative demand for the whole country, and summarizes inequality as manifested by consumption shares. The estimated indicator of dispersion in the sample ranges from 1.069 to 1.925 , with an average value of 1.26 .

The dispersion index is based on more information than that contained in standard inequality indexes. Standard indexes are based on the second moment or the rank order of monetary income. (See for example Atkinson 1970, 1997). For comparison, in Figure 2 we have plotted our estimated dispersion indexes against Gini coefficients (where available) for the same country-periods. Figure 3 offers a similar plot for the dispersion index and the Atkinson index of inequality. (Gini and Atkinson indexes are from Francois and RojasRomagosa, 2004. Our full set of estimates of income dispersion are reported in Annex Table 2.) Simple OLS regressions with country-specific fixed effects yield relatively good fits for both sets of data, with R-squared values of 0.86 (Gini coefficient, 79 observations) and 0.90 (Atkinson index, 72 observations). From the chart, most divergence between the dispersion index and the Atkinson index is at lower levels of inequality. With the Gini coefficient, this is concentrated more in the middle of the inequality range.

[Figures 2, 3 about here]

\section{Demand system estimates with representative consumption}

The numerical modeling literature employs a range of demand systems, from Cobb-Douglas with its fixed expenditure shares to flexible functional forms. The GTAP model, a relatively standard multi-region CGE literature, employs a constant-difference elasticity form, where Cobb-Douglas and LES preferences are then a special case. While heterogenous households are a recent addition to this literature, the standard approach involves a representative national household. (Hertel et al 1997, more cites) Similarly, in the supporting econometric 
literature, the usual proxy for tastes is the average per capita income in the country, which ignores the aggregation problem when the income within a country is unevenly distributed.

In this section we again examine the interaction between observed inequality and expenditure patterns, this time in the context of full demand system estimation, based on our cross-country expenditure, income, and household inequality data, and with the addition of ICP price data and our estimates of representative expenditure. Given our emphasis in the previous section on non-linear Engel curves, we start with estimation of a flexible demand system. We stress exact aggregation of per capita expenditure through representative expenditure in estimation of an almost-ideal demand (AID) system, instead of the average per-capita. This is followed by an examination of the implied marginal impact of changes in income levels (from the international dispersion of income in our sample) and national income distribution (from the intra-national dispersion of income in our sample) on expenditure shares.

\subsection{Demand system estimation}

From Deaton and Mulbauer (1980a,b), the AID system equations to be estimated are the following ones:

$$
\begin{gathered}
w_{i} \quad=\alpha_{i}+\sum_{j} \gamma_{i j} \log p_{j}+\beta_{i} \log \frac{x}{P} \\
=\alpha_{i}+\sum_{j} \log p_{j}+\beta_{i} \log x-\beta_{i} \log P \\
\log P=\alpha_{o}+\sum_{k} \alpha_{k} \log p_{k}+1 / 2 \sum_{k} \sum_{l} \log p_{k} \log p
\end{gathered}
$$

where $w_{i}$ is the expenditure share for good $i, p_{j}$ are the prices for goods $j, x$ is expenditure and $P$ is a price index. The condition of adding up requires:

$$
\sum_{k} \alpha_{k}=1, \sum_{k} \beta_{k}=1, \sum_{k} \gamma_{k j}=0
$$

Homogeneity is satisfied if and only if, for all $j$ :

$$
\sum_{k} \gamma_{j k}=0
$$


and symmetry is satisfied provided:

$$
\gamma_{j i}=\gamma_{i j}
$$

The unrestricted estimation of the model given by equation (7) will satisfy automatically the adding-up restrictions, though homogeneity and symmetry have to be tested for by imposing the conditions given by (10) and (11). The AID system is not only almost ideal but also almost linear, because the only term that causes nonlinearity is $\beta_{i} \log P$ in equation (7). Stone's price index can be introduced, an option suggested by Deaton and Muellbauer, which can be computed before the analysis and used then in the estimation of (7). Then, only the equation (7) has to be estimated. The log of this price index is:

$$
\log P=\sum_{k} w_{k} p_{k}
$$

We want to include the effect of an unequal income distribution within countries in this demand flexible system. Accordingly, following Deaton and Muellbauer, we use representative instead of average per capita income in our regressions. With this approach, "representative expenditure allows a straightforward and extremely elegant way of introducing distributional and demographic considerations into demand equations" (Deaton and Muellbauer 1980 b, p. 158).

SUR estimates of the unrestricted AID system using representative expenditures are shown in the top section of Table 3. A logistic transformation has been employed as we are working with share data. The representative consumption expenditure $x_{o}$ is significant in all goods but furniture, with two necessities - food and clothing, with a negative sign for $x_{o}$. The rest are luxuries - rents, medical care, transport, recreation and other consumption goods again with a negative sign for $x_{o}$. This is expected given the logistic transformation. In average, theses goods represent the $92.37 \%$ of total consumption expenditure in this sample, so that it is representative enough for the whole set of goods and total expenditure. The last category is omitted to force additivity in the regressions. (When additivity is not imposed, for the last category "other," $x_{o}$ is also significant. The sign is negative in that case.)

(Table 3 about here) 
The bottom section of Table 3 reports SUR estimates with a restricted model, where we try to conserve degrees of freedom by pooling prices in the slope $\alpha$, so that only real per capita representative consumption is considered as an explanatory variable. It is divided into the two usual components: representative expenditure and a price index. When this restricted system is estimated, our classification of necessities and luxuries remains the same, while for all of the aggregate categories we find a significant relationship between consumption shares and the representative expenditure. While the restricted system is useful for isolating the effect of representative consumption, the log likelihood indicator shows a better fit for the unrestricted model where all prices are considered explicitly. Finally, we have also tested for both homogeneity and symmetry by imposing the restrictions in equations (10) and (11). Based on log-likelihood ratios and the corresponding critical $X^{2}$ values for every restricted model, the estimated demand functions are as a whole non-homogeneous and non-symmetric.

\subsection{Income dispersion and marginal income effects}

We turn next to the marginal impact of changes national income levels and dispersion on expenditure shares. This exercise is similar to the one based on Engel curves, though we now work with our demand system estimates. Table 4 reports estimates of the incremental change in expenditure shares that follows from a unit change in national income (an extra dollar percapita). For each expenditure category, we have first estimated this value for the average sample value of income and average dispersion level in the sample. We then have proceeded to make similar calculations, at one time holding dispersion constant while varying income, and as an alternative holding income while varying dispersion across the minimum and maximum sample values. We have also done this for sub-samples of low- and high-income countries.

(Table 4 about here)

Table 4 can be read in a similar manner to Table 2. As expected, when an "average" country in the sample receives one more dollar per capita, it reduces expenditure shares in necessities and increases the ones for luxuries. This change is much larger in poor countries, showing a greater sensitivity to changes in income and greater reductions in relative food and 
clothing consumption, and larger increases in rents, medical goods and services, transport, recreation and personal services expenditures. What is striking is the marginal impact on sample variation in inter-country income levels, compare to sample variations in intracountry income dispersion. Once we move away from food, variations in income distribution mean very little for variations in the marginal impact of income changes in expenditure patterns. Even for food, we see that moving from the most equitable to the most unequal income distribution in the sample has at most a 10 percent impact on the marginal impact of income (a marginal share change of -.043 instead of -.039). This suggests that less extreme changes in intra-country income distribution (as might be expected with the policy reforms modeled in multi-sector computational models) will have at most second-order impacts on aggregate demand patterns. This is consistent with the results flagged in the discussion on Table 2. There is a statistically significant, though economically small marginal dispersion effect, always negative, which means that countries in our sample with an uneven distribution show a larger reduction in food and clothing consumption and a smaller increase in luxuries. Again, necessities demand is more sensitive in countries where income is unevenly distributed.

\section{Summary and conclusions}

In this paper we examine linkages between aggregate household income across countries (inter-country income dispersion), distribution of that income (intra-country income dispersion), and aggregate expenditure patterns in a cross-country context. With recent emphasis in the policy modeling literature on the integration of disaggregated household data into more macro-level models with representative consumers, we need a better understanding of the importance of income distribution for aggregate demand variation. We offer evidence that aggregate demand varies systematically with income distribution within countries, giving rise to distribution-driven Engel effects. This means that, at least statistically, both inter- and intra-country dispersion matter, driving observed variations in final expenditure patterns. In addition, adding information about income distribution within countries only strengthens the results reported elsewhere in the literature based purely on international variation in mean incomes. Preferences are non-homothetic. The greatest effects relate to food vis-à-vis all other goods.

At the same time, an equally important question is the economic significance of these two effects. The current emphasis in policy modeling circles on equity linkages, 
including high profile work sponsored by the World Bank, the IMF, and regional development banks, means that a better understanding of the range and magnitude of potential feedbacks in this area is policy relevant as well economically relevant. (See for example Reimer 2002, Hertel et al 2004.) We interpret our results as follows. Observed variations in demand suggest that beyond some second order substitution related to food, the economic impact of changes in equity on aggregate demand are not likely to be great in most policy modeling contexts. (The one obvious exception is changes that directly target distribution of income, such as changes in progressive tax structures or the distribution of benefits and subsidies.) We conclude that computational modeling based on an appropriately specified aggregate household, with side calculations related to equity, should therefore be sufficient in many circumstances.

Finally, we also present an alternative set of inequality indexes. These are income dispersion indexes, and embody information on how income inequality interacts with variations in expenditure patterns. These consumption variance indexes perform in a similar manner to Gini coefficients and Atkinson indexes, with similar patterns of variation across countries and time. 


\section{References}

Atkinson, A.B. (1970), "On the Measurement of Inequality, " Journal of Economic Theory, 2: 244-63.

Atkinson, A.B. (1997), "Bringing Income Distribution in from the Cold", Economic Journal, 107: 297-321.

Cogneau D. and Robilliard A.-S. ( 2000), "Growth, Distribution and Poverty in Madagascar Learning from a Microsimulation Model in a General Equilibrium Framework", IFPRI, DMT Discussion Paper No 61.

Deaton, A. and Muellbauer, J. (1980a), "An Almost Ideal Demand System", American Economic Review, vol. 70, pp. 312-336.

Deaton, A. and Muellbauer, J. (1980b), Economics and consumer, Cambridge, Cambridge University Press.

Devarajan, B. and van der Mansbrugghe, G. (2000), "Trade Reform in South Africa: Impacts on Households. Conference on Poverty and the International Economy," World Bank and The Parliamentary Commission on Swedish Policy for Global Development. Stockholm.

Edgerton, D.L. et al (1996), The Econometrics of Demand Systems. With Applications to Food Demand in the Nordic Countries, Advanced Studies in Theoretical and Applied Econometrics, Massachussets, Kluwer Academic Publishers.

Fillat, C. (1997), "Desarrollo economico y evolucion del patron comercial espanol. Complementariedad y relatividad de las teorias de comercio", Informacion Comercial Espanola, n. 765, pp. 115-134.

Francois, J. and Kaplan, S. (1996), "Aggregate Demand Shifts, Income Distribution, and the Linder Hypothesis, " The Review of Economics and Statistics, vol. 78 (2), pp. 244250.

Francois, J. and Rojas-Romagosa, H. (2004), "The Construction and Interpretation of Combined Cross-Section and Time-Series Income Inequality Datasets, " Tinbergen Institute discussion paper.

Hertel, T. W., M. Ivanic, P.V. Preckel, and J. A. Cranfield, "The Earnings Effects of Multilateral Trade Liberalization: Implications for Poverty in Developing Countries", forthcoming World Bank Economic Review, 2004.

Hoa, T.V. et al (1983), "Energy consumption in Australia. Evidence from a Generalized Working Model", Economic Letters, 12, pp. 383-389. 
Ianchovichina, E.; Nicita, A. and Soloaga, Isidro (2002), "Trade Reform and Poverty: the Case of Mexico", World Economy, 25 (7), pp. 945-972.

Khan, F.C. (1997): "Household Disaggregation", Francois, J. and Reinert, K.A. (1997): Applied Methods for Trade Policy Analysis, Cambridge, Cambridge University Press, pp.300-327.

Lesser, C.E.V. (1976): "Income, Household Size and Price Changes 1953-1973", OxfordBulletin-of-Economics-and-Statistics; 38(1), pp. 1-10.

Penn World Table 5.6.: http://cansim.epas.utoronto.ca:5680/pwt/index.html.

Reimer, J.J. (2002), "Estimating the Poverty Impacts of Trade Liberalization." World Bank Policy Research Working Paper 2790. February.

Reimer J.J., and T. Hertel (2003), "International cross Section Estimates of Demand for Use in the GTAP Model, "Centre for Global Trade Analysis, Global Trade Analysis Project Working Paper No. 22

Robillard, A-S, F. Bourguignon and S. Robinson (2001), "Crisis and Income Distribution: A Micro-Macro Model for Indonesia, " World Bank working paper, June.

Winters, L. Alan. 2001. "Trade, Trade Policy, and Poverty: What are the Links?" Centre for Economic Policy Research Paper No. 2382.

Winters, L.A., N. McCulloch, and A. McKay. 2003. "Trade Liberalization and Poverty: The Empirical Evidence", working paper, University of Sussex, Institute of Development Studies.

World Bank: World Development Indicators Data Base. 
Table 1: Engel curves estimates

\begin{tabular}{|c|c|c|}
\hline & $\lambda_{i}$ & $\mu_{i}$ \\
\hline 1. Food, beverages, tobacco & $\begin{array}{r}0.846885 \\
(4.075030)\end{array}$ & $\begin{array}{r}-0.11399 \\
-(0.97931)\end{array}$ \\
\hline 2. Clothing and footwear & $\begin{array}{r}0.092204 \\
(3.710630)\end{array}$ & $\begin{array}{r}-0.00312 \\
-(0.49079)\end{array}$ \\
\hline 3. Rents, fuel and power & $\begin{array}{r}-0.000048 \\
-(0.000802)\end{array}$ & $\begin{array}{r}0.02991 \\
(0.96481)\end{array}$ \\
\hline 4. Furniture, household equipment and operation & $\begin{array}{r}0.085535 \\
(3.481130)\end{array}$ & $\begin{array}{r}-0.00236 \\
-(0.39265)\end{array}$ \\
\hline 5. Medical care and pharmaceutical products & $\begin{array}{r}-0.027549 \\
-(0.609983)\end{array}$ & $\begin{array}{r}0.02106 \\
(0.94968)\end{array}$ \\
\hline 6. Transport and communication & $\begin{array}{r}0.015758 \\
(0.362490)\end{array}$ & $\begin{array}{r}0.01995 \\
(0.94334)\end{array}$ \\
\hline 7. Recreation, entertainment and education & $\begin{array}{r}0.056972 \\
(1.814890)\end{array}$ & $\begin{array}{r}0.01104 \\
(0.88076)\end{array}$ \\
\hline 8. Other & $\begin{array}{r}-0.065379 \\
-(0.934039)\end{array}$ & $\begin{array}{r}0.03627 \\
(0.96972)\end{array}$ \\
\hline & \multicolumn{2}{|c|}{$\delta$} \\
\hline Cross-equation estimate & \multicolumn{2}{|c|}{$\begin{array}{c}-0.09253 \\
(29.0868)\end{array}$} \\
\hline
\end{tabular}

$\mathrm{t}$-statistics in parentheses

number of observations $=1,344$

Log-likelihood $=2002.90$

Adjusted $\mathrm{R}^{2}=0.75$ 
Table 2, Engel curve decomposition

\begin{tabular}{|c|c|c|c|c|c|}
\hline \multirow[b]{2}{*}{ 1. Food } & & \multicolumn{3}{|c|}{ consumption shares } & \multirow[b]{2}{*}{ dispersion effect } \\
\hline & & average & $\max$ & $\min$ & \\
\hline & average & 0.266 & 0.243 & 0.275 & -0.032 \\
\hline & poor & 0.352 & 0.333 & 0.360 & -0.027 \\
\hline & rich & 0.244 & 0.220 & 0.253 & -0.033 \\
\hline & income effect & -0.109 & -0.113 & -0.107 & \\
\hline
\end{tabular}

\begin{tabular}{|lrrrr|}
\hline \multirow{2}{*}{ 2. Clothing } & \multicolumn{5}{c|}{ consumption shares } & \multirow{2}{*}{ average } \\
& & & & \\
& 0.076 & 0.076 & 0.077 & -0.001 \\
average & 0.079 & 0.078 & 0.079 & -0.001 \\
poor & 0.076 & 0.075 & 0.076 & -0.001 \\
rich & -0.003 & -0.003 & -0.003 & \\
income effect & & & & \\
& &
\end{tabular}

\begin{tabular}{|lrrrr|}
\hline 3. Rents & \multicolumn{4}{c|}{ consumption shares } \\
& average & $\max$ & $\min$ & dispersion effect \\
& & & & \\
& 0.152 & 0.158 & 0.150 & 0.008 \\
average & 0.130 & 0.135 & 0.128 & 0.007 \\
poor & 0.158 & 0.165 & 0.156 & 0.009 \\
rich & 0.029 & 0.030 & 0.028 & \\
income effect & & & & \\
\hline
\end{tabular}

\begin{tabular}{|c|c|c|c|c|}
\hline \multirow[b]{2}{*}{ 4. Furniture } & \multicolumn{3}{|c|}{ consumption shares } & \multirow[b]{2}{*}{ dispersion effect } \\
\hline & average & $\max$ & $\min$ & \\
\hline average & 0.074 & 0.073 & 0.074 & -0.001 \\
\hline poor & 0.075 & 0.075 & 0.075 & -0.001 \\
\hline rich & 0.073 & 0.073 & 0.073 & -0.001 \\
\hline income effect & -0.002 & -0.002 & -0.002 & \\
\hline
\end{tabular}

\begin{tabular}{|llr|}
\hline Per capita expenditure & Average poor & 542.57 \\
& Average richer & 6713.63 \\
& Average country in the sample & 3628.10 \\
\hline
\end{tabular}

\begin{tabular}{|c|c|c|c|c|c|}
\hline \multirow[b]{2}{*}{ 5. Medical } & \multicolumn{5}{|c|}{ consumption shares } \\
\hline & & average & $\max$ & $\min$ & dispersion effect \\
\hline & average & 0.080 & 0.084 & 0.078 & 0.006 \\
\hline & poor & 0.064 & 0.067 & 0.062 & 0.005 \\
\hline & rich & 0.084 & 0.088 & 0.082 & 0.006 \\
\hline & income effect & 0.020 & 0.021 & 0.020 & \\
\hline
\end{tabular}

\begin{tabular}{|c|c|c|c|c|}
\hline \multirow[b]{2}{*}{ 6. Transport } & \multicolumn{3}{|c|}{ consumption shares } & \multirow[b]{2}{*}{ dispersion effect } \\
\hline & average & $\max$ & $\min$ & \\
\hline average & 0.117 & 0.121 & 0.116 & 0.006 \\
\hline poor & 0.102 & 0.106 & 0.101 & 0.005 \\
\hline rich & 0.121 & 0.126 & 0.120 & 0.006 \\
\hline income effect & 0.019 & 0.020 & 0.019 & \\
\hline
\end{tabular}

\begin{tabular}{|lcccr|}
\hline 7. Recreation & \multicolumn{4}{c}{ consumption shares } \\
& average & $\max$ & $\min$ & dispersion effect \\
average & 0.113 & 0.115 & 0.112 & 0.003 \\
poor & 0.105 & 0.107 & 0.104 & 0.003 \\
rich & 0.115 & 0.118 & 0.115 & 0.003 \\
income effect & 0.011 & 0.011 & 0.010 & \\
\hline
\end{tabular}

\begin{tabular}{|c|c|c|c|c|c|}
\hline \multirow[b]{2}{*}{ 8. Other } & \multicolumn{5}{|c|}{ consumption shares } \\
\hline & & average & $\max$ & $\min$ & dispersion effect \\
\hline & average & 0.119 & 0.127 & 0.117 & 0.010 \\
\hline & poor & 0.092 & 0.098 & 0.090 & 0.009 \\
\hline & rich & 0.127 & 0.134 & 0.124 & 0.011 \\
\hline & income effect & 0.035 & 0.036 & 0.034 & \\
\hline
\end{tabular}

\begin{tabular}{|llr|}
\hline Average population per quintil & Poor & 11259.87 \\
& Rich & 7800.8 \\
& Average & 9530.33 \\
\hline
\end{tabular}


Table 3, Unrestricted and restricted S.U.R. demand system estimates

\begin{tabular}{|c|c|c|c|c|c|c|c|c|c|c|c|c|c|}
\hline \multirow[b]{2}{*}{ unrestricted model: Log Likelihood=-3474.565 } & $\alpha$ & $\log \mathrm{p} 1$ & $\log \mathrm{p} 2$ & $\log \mathrm{p} 3$ & $\log \mathrm{p} 4$ & $\log \mathrm{p} 5$ & $\log \mathrm{p} 6$ & $\log \mathrm{p} 7$ & $\log \mathrm{p} 8$ & $\log$ xo & \multicolumn{2}{|l|}{$-\log P$} & \multirow[t]{2}{*}{$\operatorname{adj} R^{2}$} \\
\hline & & & & & & & & & & & & & \\
\hline 1.Food, beverages, tobacco & $\begin{array}{r}1.578 \\
(1.227)\end{array}$ & $\begin{array}{r}0.391 \\
(3.568)\end{array}$ & $\begin{array}{r}-0.137 \\
-(1.466)\end{array}$ & $\begin{array}{r}-0.092 \\
-(1.740)\end{array}$ & $\begin{array}{r}0.082 \\
(0.884)\end{array}$ & $\begin{array}{r}-0.013 \\
-(0.253)\end{array}$ & $\begin{array}{r}0.136 \\
(1.911)\end{array}$ & $\begin{array}{r}-0.347 \\
-(5.899)\end{array}$ & $\begin{array}{r}-0.035 \\
-(1.858)\end{array}$ & $\begin{array}{r}-0.382 \\
-(1.923)\end{array}$ & $\begin{array}{r}-0.023 \\
-(1.726)\end{array}$ & * & 0.83 \\
\hline 2.Clothing and footwear & $\begin{array}{r}-2.116 \\
-(1.546)\end{array}$ & $\begin{array}{r}-0.297 \\
-(2.546)\end{array}$ & $\begin{array}{r}0.326 \\
(3.277)\end{array}$ & $\begin{array}{r}-0.073 \\
-(1.305)\end{array}$ & $\begin{array}{r}0.077 \\
(0.776)\end{array}$ & $\begin{array}{r}-0.088 \\
-(1.657)\end{array}$ & $\begin{array}{r}-0.054 \\
-(0.708)\end{array}$ & $\begin{array}{r}0.085 \\
(1.357)\end{array}$ & $\begin{array}{r}0.041 \\
(2.052)\end{array}$ & $\begin{array}{r}-0.063 \\
-(2.992)\end{array}$ & $\begin{array}{r}0.021 \\
(1.491)\end{array}$ & $*$ & 0.13 \\
\hline 3. Rents, fuel and power & $\begin{array}{r}-3.516 \\
-(2.091)\end{array}$ & $\begin{array}{r}0.151 \\
(1.051)\end{array}$ & $\begin{array}{r}-0.161 \\
-(1.319)\end{array}$ & $\begin{array}{r}0.160 \\
(2.322)\end{array}$ & $\begin{array}{r}-0.226 \\
-(1.853)\end{array}$ & $\begin{array}{r}-0.081 \\
-(1.244)\end{array}$ & $\begin{array}{r}0.058 \\
(0.622)\end{array}$ & $\begin{array}{r}0.138 \\
(1.796)\end{array}$ & $\begin{array}{r}-0.012 \\
-(0.508)\end{array}$ & $\begin{array}{r}0.254 \\
(9.775)\end{array}$ & $\begin{array}{r}0.016 \\
(0.892)\end{array}$ & * & 0.47 \\
\hline 4.Furniture, household equipment and operation & $\begin{array}{r}-2.642 \\
-(1.856)\end{array}$ & $\begin{array}{r}-0.505 \\
-(4.167)\end{array}$ & $\begin{array}{r}0.291 \\
(2.811)\end{array}$ & $\begin{array}{r}0.077 \\
(1.311)\end{array}$ & $\begin{array}{r}0.036 \\
(0.345)\end{array}$ & $\begin{array}{r}0.120 \\
(2.181)\end{array}$ & $\begin{array}{r}-0.118 \\
-(1.498)\end{array}$ & $\begin{array}{r}0.072 \\
(1.100)\end{array}$ & $\begin{array}{r}0.019 \\
(0.909)\end{array}$ & $\begin{array}{r}0.018 \\
(0.836)\end{array}$ & $\begin{array}{r}0.018 \\
(1.253)\end{array}$ & & 0.19 \\
\hline 5.Medical care and pharmaceutical products & $\begin{array}{r}-3.897 \\
-(1.774)\end{array}$ & $\begin{array}{r}-0.547 \\
-(2.924)\end{array}$ & $\begin{array}{r}0.134 \\
(0.837)\end{array}$ & $\begin{array}{r}0.078 \\
(0.862)\end{array}$ & $\begin{array}{r}0.173 \\
(1.084)\end{array}$ & $\begin{array}{r}0.150 \\
(1.765)\end{array}$ & $\begin{array}{r}-0.388 \\
-(3.194)\end{array}$ & $\begin{array}{r}0.385 \\
(3.827)\end{array}$ & $\begin{array}{r}0.031 \\
(0.955)\end{array}$ & $\begin{array}{r}0.187 \\
(5.510)\end{array}$ & $\begin{array}{r}0.033 \\
(1.461)\end{array}$ & $*$ & 0.46 \\
\hline 6.Transport and communication & $\begin{array}{r}-3.779 \\
-(1.808)\end{array}$ & $\begin{array}{r}-0.467 \\
-(2.622)\end{array}$ & $\begin{array}{r}0.297 \\
(1.956)\end{array}$ & $\begin{array}{r}0.045 \\
(0.524)\end{array}$ & $\begin{array}{r}-0.237 \\
-(1.565)\end{array}$ & $\begin{array}{r}-0.037 \\
-(0.456)\end{array}$ & $\begin{array}{r}0.185 \\
(1.603)\end{array}$ & $\begin{array}{r}0.248 \\
(2.593)\end{array}$ & $\begin{array}{r}-0.021 \\
-(0.695)\end{array}$ & $\begin{array}{r}0.248 \\
(7.662)\end{array}$ & $\begin{array}{r}0.019 \\
(0.874)\end{array}$ & * & 0.45 \\
\hline 7.Recreation, entertainment and education & $\begin{array}{r}-2.754 \\
-(1.468) \\
\end{array}$ & $\begin{array}{r}-0.346 \\
-(2.167) \\
\end{array}$ & $\begin{array}{r}-0.048 \\
-(0.355) \\
\end{array}$ & $\begin{array}{r}0.085 \\
(1.105) \\
\end{array}$ & $\begin{array}{r}0.014 \\
(0.106) \\
\end{array}$ & $\begin{array}{r}0.080 \\
(1.096) \\
\end{array}$ & $\begin{array}{r}-0.146 \\
-(1.412) \\
\end{array}$ & $\begin{array}{r}0.366 \\
(4.266) \\
\end{array}$ & $\begin{array}{r}0.031 \\
(1.131) \\
\end{array}$ & $\begin{array}{r}0.097 \\
(3.350) \\
\end{array}$ & $\begin{array}{r}0.021 \\
(1.088) \\
\end{array}$ & * & 0.31 \\
\hline restricted model: $\log$ Likelihood=-4257.51 & & & & & & & & & & & & & \\
\hline 1.Food, beverages, tobacco & $\begin{array}{r}1.913 \\
(16.706)\end{array}$ & & & & & & & & & $\begin{array}{r}-0.433 \\
-(23.204)\end{array}$ & $\begin{array}{r}-0.013 \\
-(1.329)\end{array}$ & * & 0.77 \\
\hline 2.Clothing and footwear & $\begin{array}{r}-2.259 \\
-(20.553)\end{array}$ & & & & & & & & & $\begin{array}{r}-0.041 \\
-(2.303)\end{array}$ & $\begin{array}{r}0.005 \\
(0.591)\end{array}$ & * & 0.03 \\
\hline 3.Rents, fuel and power & $\begin{array}{r}-3.409 \\
-(25.738)\end{array}$ & & & & & & & & & $\begin{array}{r}0.238 \\
(11.010)\end{array}$ & $\begin{array}{r}0.003 \\
(0.295)\end{array}$ & $*$ & 0.43 \\
\hline 4.Furniture, household equipment and operation & $\begin{array}{r}-2.930 \\
-(25.128)\end{array}$ & & & & & & & & & $\begin{array}{r}0.062 \\
(3.257)\end{array}$ & $\begin{array}{r}0.024 \\
(2.407)\end{array}$ & * & 0.06 \\
\hline 5.Medical care and pharmaceutical products & $\begin{array}{r}-4.525 \\
-(24.416)\end{array}$ & & & & & & & & & $\begin{array}{r}0.280 \\
(9.258)\end{array}$ & $\begin{array}{r}0.034 \\
(2.161)\end{array}$ & * & 0.33 \\
\hline 6.Transport and communication & $\begin{array}{r}-4.027 \\
-(24.471)\end{array}$ & & & & & & & & & $\begin{array}{r}0.289 \\
(10.787)\end{array}$ & $\begin{array}{r}0.025 \\
(1.795)\end{array}$ & $*$ & 0.41 \\
\hline 7.Recreation, entertainment and education & $\begin{array}{r}-3.209 \\
-(20.926) \\
\end{array}$ & & & & & & & & & $\begin{array}{r}0.164 \\
(6.549)\end{array}$ & $\begin{array}{r}0.007 \\
(0.531)\end{array}$ & $*$ & 0.20 \\
\hline
\end{tabular}

t-statistics in parentheses, additivity imposed, total observations 1176, * denotes significant representative per-capita expenditure. 
Table 4, Marginal income effects (percent change in shares with one more dollar of per-capita income)

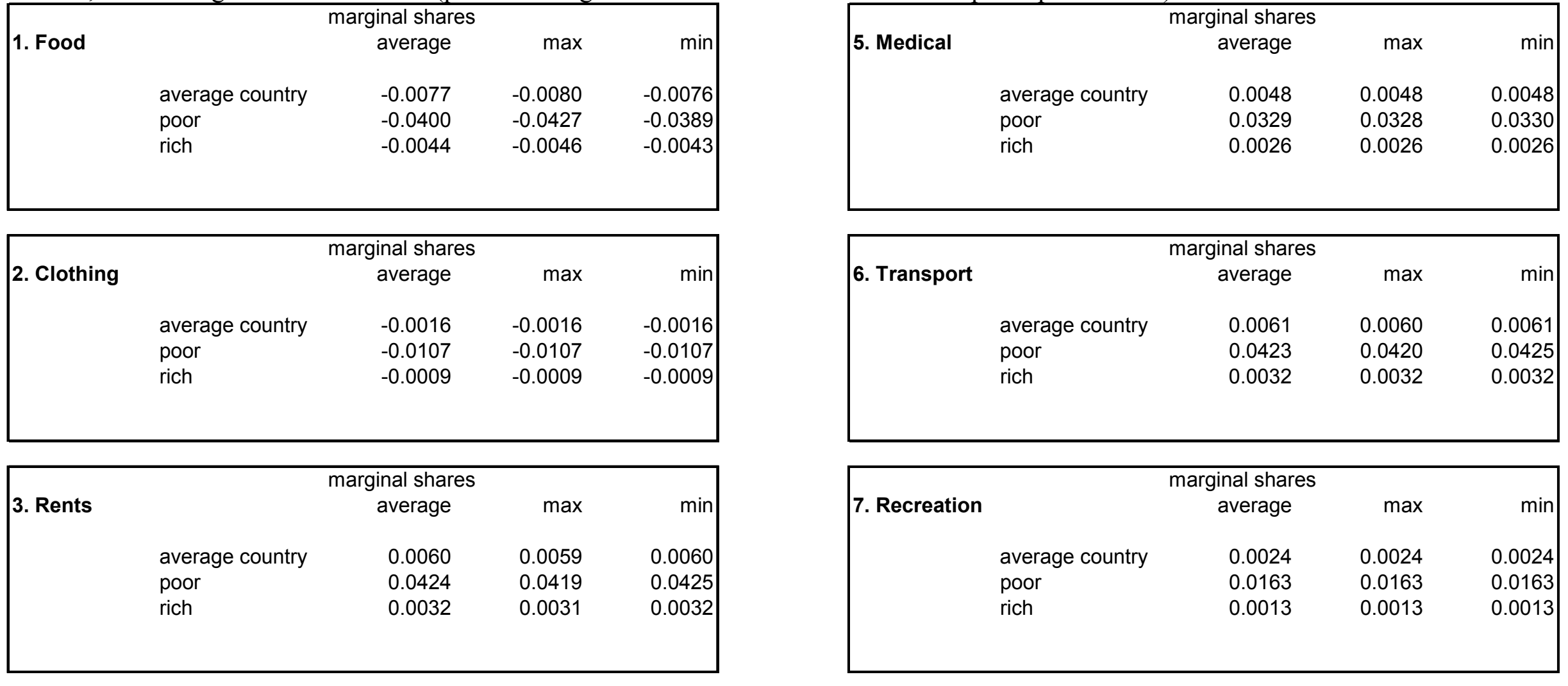

\begin{tabular}{|llrrr|}
\hline 4. Furniture & & $\begin{array}{c}\text { marginal shares } \\
\text { average }\end{array}$ & $\max$ & $\min$ \\
& & & & 0.0005 \\
& average country & 0.0005 & 0.0005 & 0.0031 \\
& poor & 0.0031 & 0.0031 & 0.0003 \\
& rich & 0.0003 & 0.0003 & \\
& & & & \\
\hline
\end{tabular}




\begin{tabular}{|c|c|c|c|c|c|c|c|}
\hline \multicolumn{8}{|c|}{ Annex Table 1: Countries and years in the sample } \\
\hline \multirow[t]{2}{*}{ Australia } & 1985 & Germany & 1980 & Luxembourg & 1975 & Senegal & 1980 \\
\hline & 1990 & & 1985 & & 1980 & & 1985 \\
\hline \multirow[t]{4}{*}{ Austria } & 1975 & & 1990 & & 1985 & Sierra Leone & 1985 \\
\hline & 1980 & Greece & 1980 & & 1990 & Spain & 1975 \\
\hline & 1985 & & 1985 & Madagascar & 1980 & & 1980 \\
\hline & 1990 & & 1990 & & 1985 & & 1985 \\
\hline Bangladesh & 1985 & Guatemala & 1980 & Malaysia & 1970 & & 1990 \\
\hline \multirow[t]{5}{*}{ Belgium } & 1970 & Honduras & 1980 & & 1975 & Sri Lanka & 1975 \\
\hline & 1975 & Hong Kong & 1980 & Mali & 1980 & & 1980 \\
\hline & 1980 & & 1985 & & 1985 & & 1985 \\
\hline & 1985 & Hungary & 1970 & Mauritius & 1985 & Sweden & 1985 \\
\hline & 1990 & & 1975 & Morocco & 1980 & & 1990 \\
\hline \multirow[t]{2}{*}{ Botswana } & 1980 & & 1980 & & 1985 & Switzerland & 1990 \\
\hline & 1985 & & 1985 & Nepal & 1985 & Tanzania & 1980 \\
\hline \multirow[t]{3}{*}{ Canada } & 1980 & India & 1970 & Netherlands & 1970 & & 1985 \\
\hline & 1985 & & 1975 & & 1975 & Thailand & 1975 \\
\hline & 1990 & & 1980 & & 1980 & & 1985 \\
\hline Chile & 1980 & & 1985 & & 1985 & Trinidad & 1985 \\
\hline \multirow[t]{3}{*}{ Colombia } & 1970 & Indonesia & 1980 & & 1990 & Tunisia & 1980 \\
\hline & 1975 & Ireland & 1975 & New Zealand & 1985 & & 1985 \\
\hline & 1980 & & 1980 & & 1990 & Turkey & 1985 \\
\hline \multirow[t]{2}{*}{ C.Marfil } & 1980 & & 1985 & Nigeria & 1980 & & 1990 \\
\hline & 1985 & & 1990 & & 1985 & United Kingdom & 1970 \\
\hline Costa Rica & 1980 & Italy & 1970 & Norway & 1980 & & 1975 \\
\hline \multirow[t]{4}{*}{ Dinamarca } & 1975 & & 1975 & & 1985 & & 1980 \\
\hline & 1980 & & 1980 & & 1990 & & 1985 \\
\hline & 1985 & & 1985 & Pakistan & 1975 & & 1990 \\
\hline & 1990 & & 1990 & & 1980 & United States & 1970 \\
\hline Dominican Republic & 1980 & Jamaica & 1975 & & 1985 & & 1975 \\
\hline Ecuador & 1980 & & 1985 & Panama & 1980 & & 1980 \\
\hline Egypt, Arab Rep. & 1985 & Japan & 1970 & Paraguay & 1980 & & 1985 \\
\hline El Salvador & 1980 & & 1975 & Philippines & 1970 & & 1990 \\
\hline \multirow[t]{2}{*}{ Ethiopia } & 1980 & & 1980 & & 1975 & Venezuela & 1980 \\
\hline & 1985 & & 1985 & & 1980 & Zambia & 1975 \\
\hline \multirow[t]{3}{*}{ Finland } & 1980 & & 1990 & & 1985 & & 1980 \\
\hline & 1985 & Kenya & 1970 & Poland & 1975 & & 1985 \\
\hline & 1990 & & 1975 & & 1980 & Zimbawe & 1980 \\
\hline \multirow[t]{5}{*}{ France } & 1970 & & 1980 & & 1985 & & 1985 \\
\hline & 1975 & & 1985 & Portugal & 1980 & & \\
\hline & 1980 & Korea, Rep. & 1970 & & 1985 & & \\
\hline & 1985 & & 1975 & & 1990 & & \\
\hline & 1990 & & 1980 & Romania & 1975 & & \\
\hline \multirow[t]{2}{*}{ Germany } & 1970 & & 1985 & Rwanda & 1985 & & \\
\hline & 1975 & & & & & & \\
\hline
\end{tabular}


Annex Table 2, Income dispersion parameter

\begin{tabular}{|c|c|c|c|c|c|}
\hline \multirow[b]{2}{*}{ country } & \multicolumn{5}{|c|}{ year } \\
\hline & 1970 & 1975 & 1980 & 1985 & 1990 \\
\hline Australia & & & & 1.250 & 1.315 \\
\hline Austria & & 1.085 & 1.085 & 1.085 & 1.085 \\
\hline Bangladesh & & & & 1.248 & \\
\hline Belgium & 1.132 & 1.132 & 1.132 & 1.112 & 1.116 \\
\hline Botswana & & & 1.587 & 1.587 & \\
\hline Cost Ivory & & & 1.303 & 1.303 & \\
\hline Canada & & & 1.163 & 1.185 & 1.125 \\
\hline Chile & & & 1.416 & & \\
\hline Hong Kong (China) & & & 1.276 & 1.327 & \\
\hline Colombia & 1.590 & 1.550 & 1.421 & & \\
\hline Costa Rica & & & 1.430 & & \\
\hline Denmark & & 1.168 & 1.163 & 1.163 & 1.191 \\
\hline Dominican Republic & & & 1.327 & & \\
\hline Ecuador & & & 1.399 & & \\
\hline Egypt, Arab Rep. & & & & 1.173 & \\
\hline El Salvador & & & 1.444 & & \\
\hline Ethiopia & & & 1.280 & 1.280 & \\
\hline Finland & & & 1.182 & 1.162 & 1.114 \\
\hline France & 1.202 & 1.202 & 1.202 & 1.206 & 1.179 \\
\hline Germany & 1.190 & 1.156 & 1.157 & 1.176 & 1.130 \\
\hline Greece & & & 1.190 & 1.190 & 1.212 \\
\hline Guatemala & & & 1.449 & & \\
\hline Honduras & & & 1.856 & & \\
\hline Hungary & 1.091 & 1.074 & 1.070 & 1.094 & \\
\hline India & 1.154 & 1.140 & 1.173 & 1.175 & \\
\hline Indonesia & & & 1.203 & & \\
\hline Ireland & & 1.248 & 1.267 & 1.290 & 1.290 \\
\hline Italy & 1.204 & 1.204 & 1.161 & 1.150 & 1.146 \\
\hline Jamaica & & 1.387 & & 1.333 & \\
\hline Japan & 1.308 & 1.235 & 1.191 & 1.219 & 1.219 \\
\hline Kenya & 1.663 & 1.663 & 1.663 & 1.663 & \\
\hline Korea, Rep. & 1.195 & 1.268 & 1.279 & 1.197 & \\
\hline Luxembourg & & 1.121 & 1.121 & 1.121 & 1.121 \\
\hline Madagascar & & & 1.391 & 1.391 & \\
\hline Malaysia & 1.508 & 1.548 & & & \\
\hline Mali & & & 1.429 & 1.429 & \\
\hline Mauritius & & & & 1.270 & \\
\hline Morocco & & & 1.263 & 1.263 & \\
\hline Nepal & & & & 1.151 & \\
\hline Netherlands & 1.135 & 1.135 & 1.129 & 1.139 & 1.144 \\
\hline
\end{tabular}


Appendix Table 2, continued

\begin{tabular}{|c|c|c|c|c|c|}
\hline \multirow[b]{2}{*}{ country } & \multicolumn{5}{|c|}{ year } \\
\hline & 1970 & 1975 & 1980 & 1985 & 1990 \\
\hline New Zealand & & & & 1.222 & 1.286 \\
\hline Nigeria & & & 1.226 & 1.226 & \\
\hline Norway & & & 1.242 & 1.142 & 1.233 \\
\hline Pakistan & & 1.178 & 1.178 & 1.178 & \\
\hline Panama & & & 1.429 & & \\
\hline Paraguay & & & 1.723 & & \\
\hline Philippines & 1.469 & 1.469 & 1.393 & 1.393 & \\
\hline Poland & & 1.109 & 1.100 & 1.103 & \\
\hline Portugal & & & 1.236 & 1.236 & 1.234 \\
\hline Romania & & 1.087 & & & \\
\hline Rwanda & & & & 1.141 & \\
\hline Senegal & & & 1.568 & 1.568 & \\
\hline Sierra Leone & & & & 1.925 & \\
\hline Spain & & 1.119 & 1.119 & 1.101 & 1.178 \\
\hline Sri Lanka & & 1.215 & 1.124 & 1.400 & \\
\hline Sweden & & & & 1.163 & 1.166 \\
\hline Switzerland & & & & & 1.219 \\
\hline Tanzania & & & 1.255 & 1.255 & \\
\hline Thailand & & 1.330 & 1.434 & & \\
\hline Trinidad & & & & 1.322 & \\
\hline Tunisia & & & 1.283 & 1.283 & \\
\hline Turkey & & & & 1.352 & 1.352 \\
\hline United Kingdom & 1.122 & 1.124 & 1.126 & 1.139 & 1.184 \\
\hline United States & 1.214 & 1.219 & 1.231 & 1.266 & 1.276 \\
\hline Venezuela & & & 1.257 & & \\
\hline Zambia & & 1.526 & 1.526 & 1.526 & \\
\hline Zimbawe & & & 1.672 & 1.672 & \\
\hline
\end{tabular}


Figure 1, Relative variations in estimated expenditure shares for sample range in income levels and dispersion (calculated around mean values)

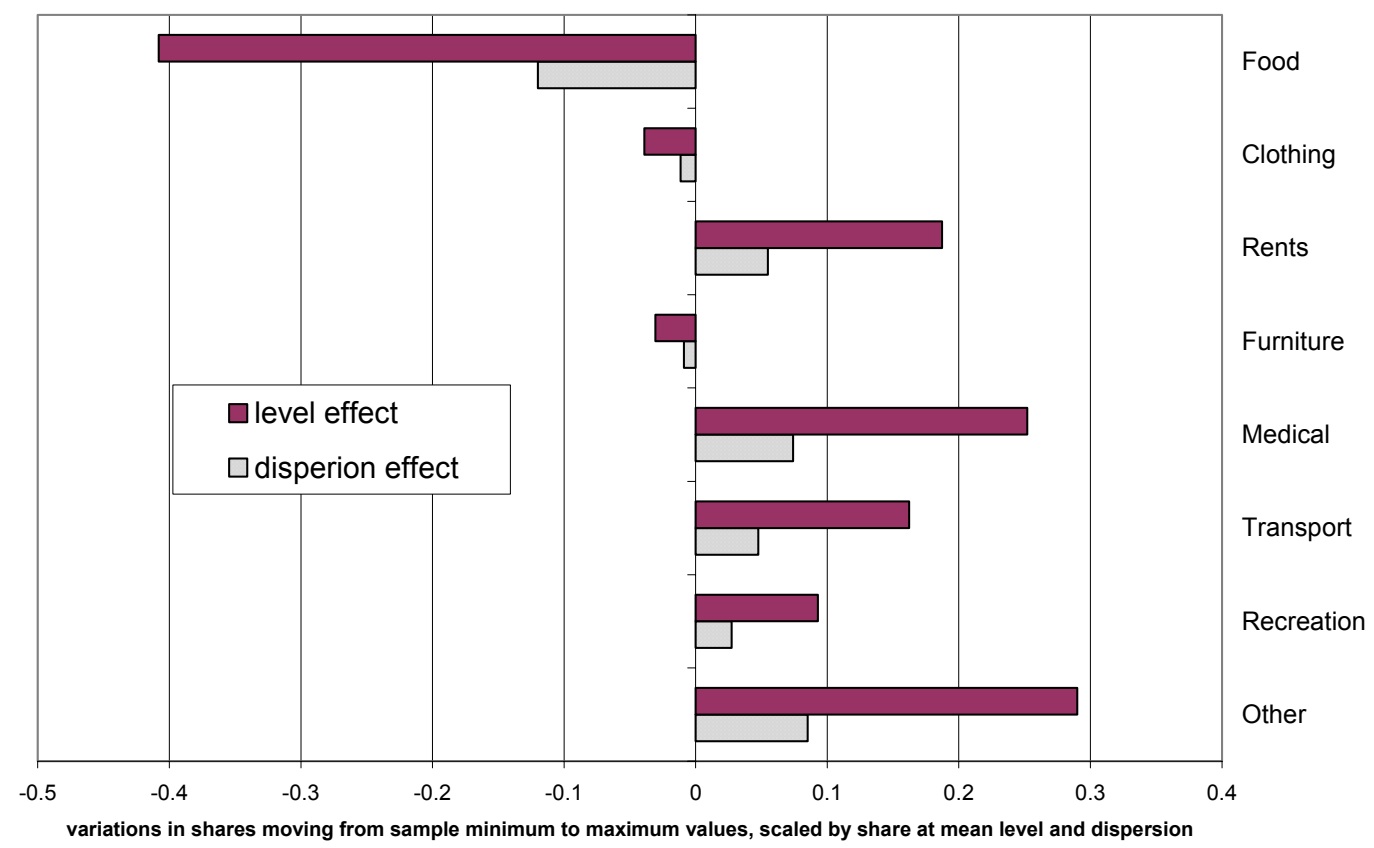


Figure 2, Gini coefficients and the income dispersion index

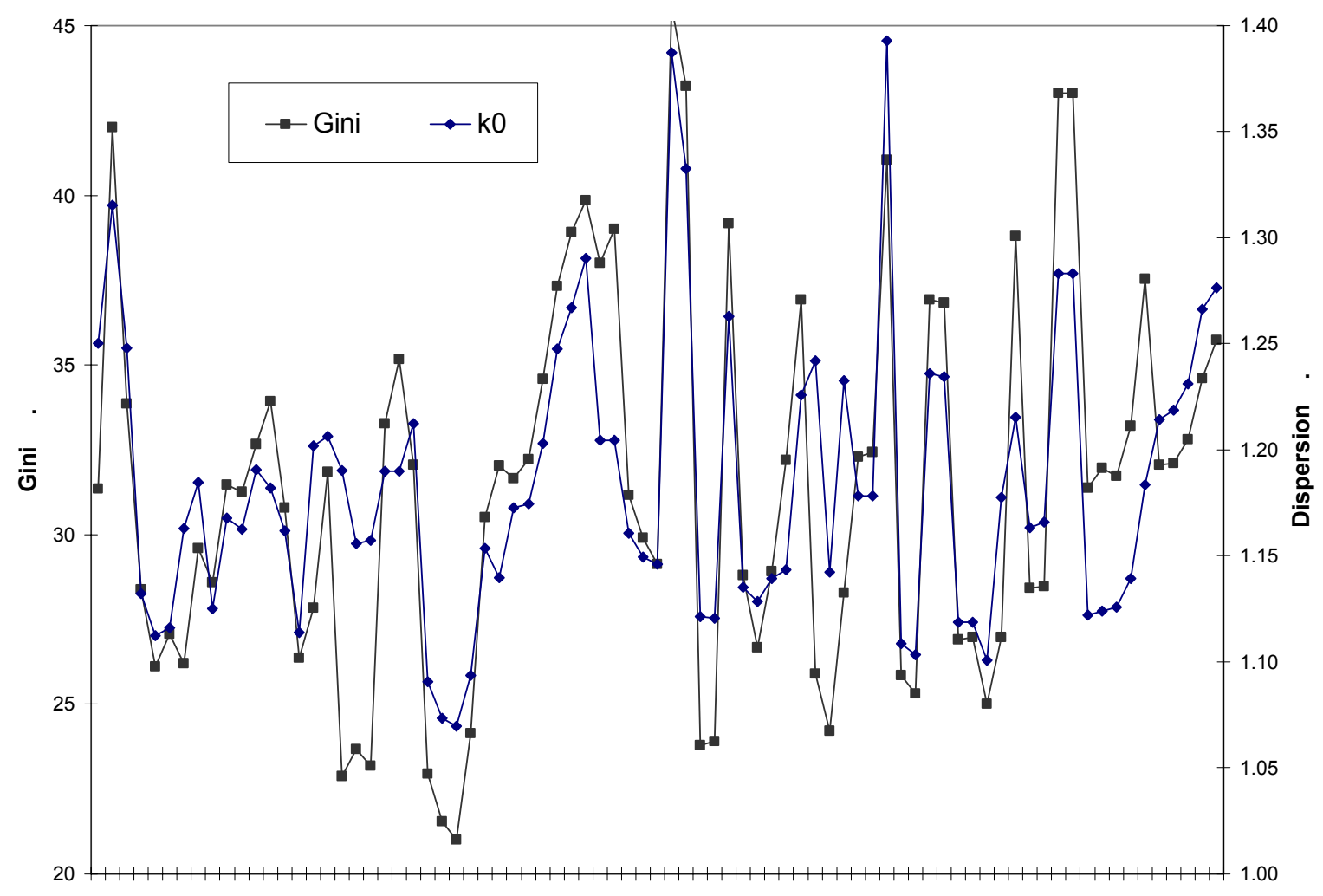

Figure 3, Atkinson index and the income dispersion index

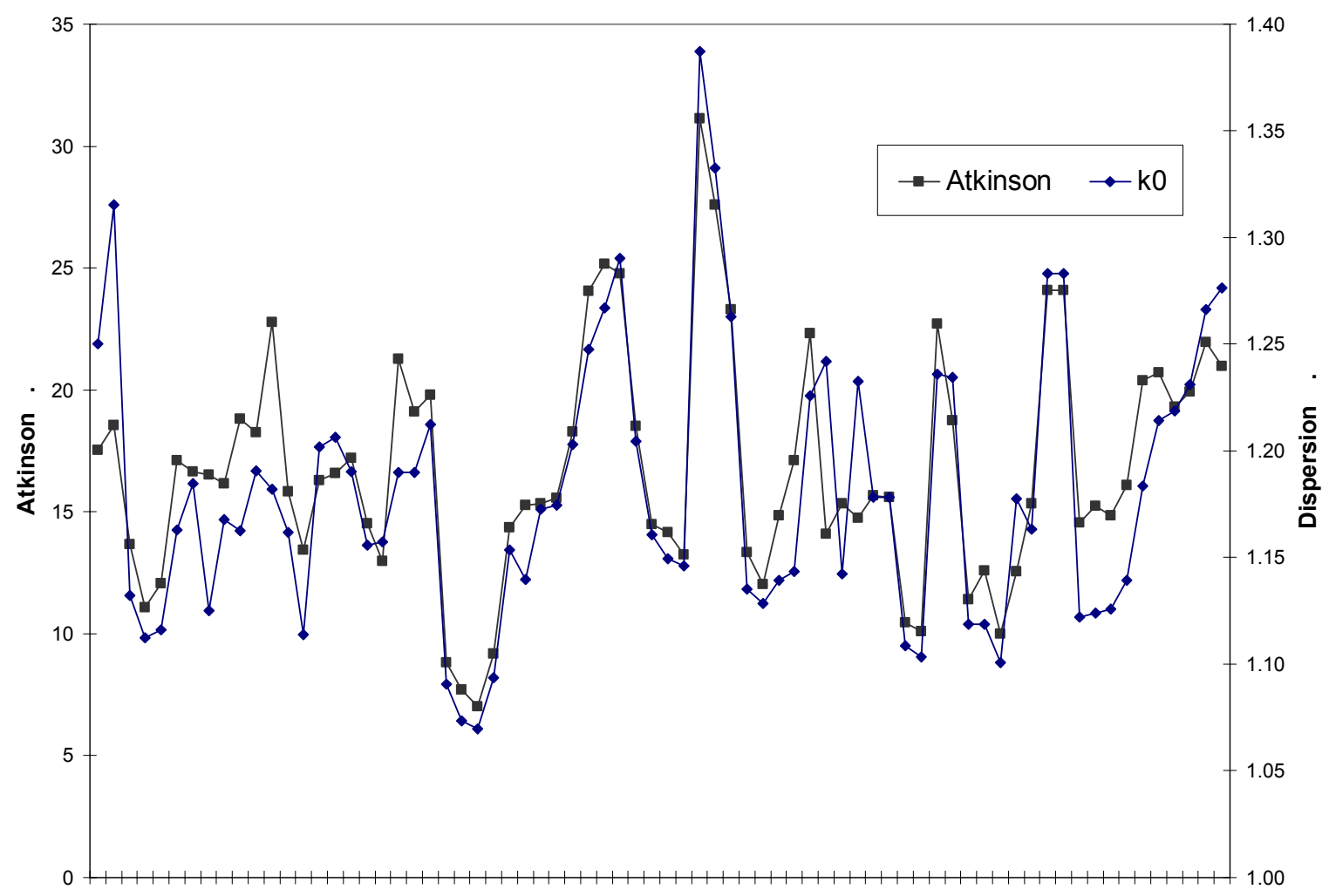

